\title{
Studies of Endophytic Actinomycetes Associated with Medicinal Plants of Mizoram, Northeast, India
}

\author{
Marcy D. Momin* and Shri Kant Tripathi \\ Department of Forestry, Mizoram University, Aizawl, Mizoram 796004, India \\ *Corresponding author
}

\section{A B S T R A C T}

Keywords

Endophytic actinomycetes, Medicinal plants, Antifungal, Plant growth promoting activities

\section{Article Info}

Accepted: 12 November 2018 Available Online: 10 December 2018
A total of 17 endophytic actinomycete strains were obtained from 6 medicinal plants of Mizoram, Northeast, India. 16S rRNA results showed $13(73.3 \%)$ of the isolates belonged to the genus Streptomyces, 2 (13.3\%) were Nocardiopsis, 1 (6.6\%) were Tsukamurella tyrosinosolvens and 1 (6.6\%) Actinobacteria bacterium. The highest number of endophytic actinomycetes was isolated from root tissue of Mikania micrantha Kunth. WI. (29.4\%) followed by stem of Mikania micrantha Kunth. WI. and rhizome of Costus speciosus (J. Konig). Eight endophytic Streptomyces showed activity against two major phytopathogenic fungi: Fusarium oxysporum $f$. sp. ciceri (MTCC-2791) and Fusarium proliferatum (MTCC-286). Six isolates showed solubilisation of inorganic phosphorous. All the isolates showed abilities to produce indole-3-acetic acid (IAA) and ammonia. These results clearly suggested that endophytic actinomycetes were alternative source as bioinoculents for plant growth promotion or as well as biocontrol agent for sustainable agricultural developments.

\section{Introduction}

Endophytes means microorganisms live inside the tissues of living plants without any effect of infection of the host plants (Strobel et al., 2004). Endophytic microorganisms are well known for production of diverse range of secondary metabolites (Strobel and Daisy, 2003; Fiedler et al., 2008; Schulz et al., 2009). The mutual relationship of microorganisms with plants found various benefits to the host plants such as production of antimicrobials, plant protection against environmental stresses, plant growth promoting phytohormones (Bailey et al., 2006; Clegg and Murray, 2000). Actinomycetes are Gram- positive bacteria, saprophytic soil inhabitants, ubiquitous in nature. Actinomycetes found as one of the important group of organisms from various plant tissues of the world (Sardi et al., 1992; De-Araujo et al., 2000; Cao et al., 2004; Coombs and Franco, 2003) including various Asteraceae family (Tanvir et al., 2014) for their producing potential bioactive compounds and various novel compounds (Igarashi et al., 2007). Among the 10,000 antimicrobial compounds produced by microorganisms, more than $50 \%$ were isolated from actinomycetes and about $60 \%$ of the bioactive compounds developed for agricultural use were originated from genus Streptomyces (Anderson and Wellington, 2001). Medicinal 
plants have been important foundations for large number of secondary metabolites which is highly used in pharmaceutical industries, food industries and further biomedical studies. According to the previous researchers, potential and high diversity of actinomycetes were examined from several medicinal plants (Khamna et al., 2009; Qin et al., 2011; Zhao et al., 2011; Taechowisan and Lumyong, 2003; Verma et al., 2009; Passari et al., 2015). Strobel and Daisy, 2003 suggested that plant selection is very tactical, plants with rare location and biology with traditional ethnobotanical history should be chosen for isolating endophytes producing novel bioactive products.

The diversity of endophytic actinomycetes may changes between different plant species and regions (Qin et al., 2011). Northeastern (NE) Region of India is a big bioprospecting area and best known for its rich biodiversity and un-tapped bioresources which has been identified as a significant position of both the Himalaya and Indo-Burma biodiversity hotspots (Myers et al., 2000). Mizoram is an important States of Northeastern India and also is a part of the 25 mega-biodiversity hotspots of the world. However, well documented medicinal plants with an ethnobatnical history has been reported more than 200 species by past researchers (Lalramnghinglova and Jha, 1998; Rai and Lalramnghinglova, 2010). There are very few reports on the studies of endophytic actinomycetes residing in the traditional medicinal plants of these regions. Therefore, endophytic actinomycetes in these regions remain unexplored and uncharacterized. This importance encouraged us to close examinations this habitat to understand the role of endophytic actinomycetes from medicinal plants of Mizoram, Northeast, India.

The present study deals with the isolation and identification of endophytic actinomycetes associated with ethno-medicinal plants of Mizoram, Northeast, India. The isolates were characterized relating with plant growth promoting activities.

\section{Materials and Methods}

\section{Collection of plant samples}

Six different medicinal plants viz., Senecio scandens Buch.-Ham. Mikania micrantha Kunth. WI, Ageratum conizoides L., Costus speciosus (J. Konig) Sm., Cassia fistula L., Scopariadulcis (Table 1) were collected from two districts, Aizawl district $\left(23^{\circ} 45^{\prime} \mathrm{N}\right.$; $92^{\circ} 38$ 'E) collection site located about $15-20 \mathrm{~km}$ from the main city and Mamit district $\left(23^{\circ} 25^{\prime} \mathrm{N}\right.$; $92^{\circ} 20^{\prime}$ E) of Mizoram, Northeast, India, $122.7 \mathrm{~km}$ distance away from the capital city Aizawl. Plants were selected based on their traditional used of medicinal plants and their abundance. Plants tissues (root, stem, petiole, flower, rhizome) were taken carefully in a sterile polythene bags and brought to the laboratory of Biotechnology, Mizoram University, Mizoram. Tissues were kept at $4^{\circ} \mathrm{C}$ and processed isolation of endophytic actinomycetes within 24-48hours of collection.

\section{Isolation of endophytic actinomycetes}

All the collected samples were washed thoroughly in running tap water to remove dust particles and organic debris. Tissues from leaves, stem, flower, root were cut into $1 \mathrm{~cm}^{2}$ small pieces and perform surface-sterilization. The sterile tissues were placed onto prepared medias: Starch Casein Agar (SCA), Starch Casein Nitrate Agar (SCNA), Tryptone Soya Agar (TSA), Glycerol Aspargine Agar (ISP 5 ) supplemented with antibiotics: Nalidixic acid to inhibit the negative gram of bacterial growth, Nystatin and Cycloheximide to suppress the fungal growth according to methods given by 
Morphological and microscopically identification of isolated endophytic actinomycetes

Dry, fuzzy, sticky, hard, filamentous colonies were observed as actinomycetes and were subculture by streaking method repeatedly till pure culture obtained (Fig. 1). Purified isolates were identified according to Bergey's Manual of Determinative Bacteriology (Holt et al., 1994). Microscopically observation for their chain morphology under Field Emission GunScanning Electron Microscopy (FEG-SEM) (Kumar et al., 2011) (Fig. 2).

\section{Molecular identification of isolated endophytic actinomycetes}

Extraction of genomic DNA was carried out by using the Pure Link Genomic DNA Extraction kit (IN-vitrogen, Carllbad, CA USAD). The 16S rRNA gene was amplified as described by Cui et al., 2001, using universal primers set PA (5'AGAGTTTGATCCTGGCTCA-3') and PH (5'-ACGGCTACCTTGTTACGACT-3'). The DNA sequencing was sent commercially (SciGenome Labs Private Ltd., Chennai, India). The sequence nucleotides of the isolates were determined through Blast search using the NCBI databases and deposited in NCBI Gen Bank.

In vitro antagonistic activity of endophytic actinomycetes

All isolates were evaluated for antagonistic activity against two major fungal phytopathogens, Fusarium oxysporum $f$. $s p$. ciceri (MTCC-2791) and Fusarium proliferatum (MTCC-286) by dual culture in vitro assay (Bredholdt et al., 2007). The pathogens were obtained from Microbial Type Culture Collection, Institute of Microbial Technology (IMTECH), Chandigarh, India. Plates with only pathogen culture were served as control. All plates were incubated at $280 \mathrm{C}$ and percentage of inhibition was calculated by using the formula $\mathrm{C}-\mathrm{T} / \mathrm{C} \times 100$, where, $\mathrm{C}$ is the colony growth of fungal pathogen in control, and $\mathrm{T}$ is the colony growth in dual culture.

\section{Phosphate solubilisation}

Qualitative phosphate solubilisation of isolates were analysed on Pikovskaya's agar media, considered to have P-solubilization to those forming clear halo zone around their colonies (Nautiyal et al., 1999).

\section{Indole acetic acid (IAA) production}

The culture was grown on $\mathrm{ISP}_{2}$ media incubated at $28^{\circ} \mathrm{C}$. Four-millimetre-diameter agar disc were cut using sterile borer and inoculated into $100 \mathrm{ml}$ of $\mathrm{ISP}_{2}$ broth containing $0.2 \%$ L-Tryptophan. The culture was grown with continuous shaker at $125 \mathrm{rpm}$. After incubation the suspension was centrifuged and $1 \mathrm{ml}$ supernatant was mixed with $2 \mathrm{ml}$ of Salkowski's reagent and further incubated in dark for 30 minutes. IAA was observed as the development of a pink-red colour (Gordon and weber, 1951).

\section{Ammonia production}

The culture was inoculated at $10 \mathrm{ml}$ of $4 \%$ peptone water and incubated in shaker at $28^{\circ} \mathrm{C}$. Subsequently, $0.5 \mathrm{ml}$ of Nessler's reagent was added to the culture and the development of brown to yellow colour indicated a positive for ammonia production (Cappucino and Sherman, 1992).

\section{Results and Discussion}

Endophytic actinomycete isolates from medicinal plants

In the present study, from various tissue samples of six different medicinal plants, total 17 number of endophytic actinomycetes were 
obtained (Table 2). According to molecular $16 \mathrm{~S}$ rRNA sequencing, the results showed that the isolates were classified into four families and four genera. Most of the isolates grouped into Streptomycetaceae (73.3\%), followed by Nocardiopsaceae $(13.3 \%)$, Tsukamurellaceae $(6.6 \%)$ and Actinomycetaceae (6.6\%) (Table 3).

\section{In vitro antagonistic activity of the isolates}

Among the 17 actinomycetes isolates, 8 (38\%) (BPSEAC1, BPSEAC7, BPSEAC8, BPSEAC16, BPSEAC18, BPSEAC23, BPSEAC31 and BPSEAC33) isolates (Table 4) showed inhibitory activity against two important, i.e. Fusarium oxysporum $f$. sp. ciceri (MTCC-2791) and Fusarium proliferatum (MTCC-286) tested pathogens (Fig. 3).

\section{Screening of plant growth promoting activities}

Out of 17 isolates, $6(35.2 \%)$ were able to solubilize inorganic phosphate and were considered as potential phosphate solubilizing isolates based on clear halo zone appearance around the colony on Pikovskaya's medium. The maximum halo zone was detected in the isolate BPSEAC4, BPSEAC5 and BPSEAC14 (Table 4). In this study, all strains showed positive for IAA production (Table 4). All 17 endophytic actinomycetes isolates were produced ammonia.

\section{Isolation and identification of endophytic actinomycetes}

To investigate the relationship among the more promising endophytic actinomycetes isolate, $16 \mathrm{~S}$ rRNA gene sequences were aligned along with the sequences of type strains retrieved from DDBJ/ EMBL/ NCBI Gen Bank databases. Analysis of the 16S rRNA gene sequence by Blast $\mathrm{N}$ with 99$100 \%$ similarity confirmed that 10 isolates could be members of genus Streptomyces (Table 3). Our results revealed that 16S rRNA gene amplification observed that Streptomyces formed a major group consistent with previous studies Zhao et al., 2011). Previous studies reported that endophytic microorganisms enter intact plant tissue by invagination of root hair cell wall, by penetration of the juncture between root hair and adjacent epidermal cells (Passari et al., 2015). The diversity of actinomycetes in the rhizosphere soils is positively correlated to the plant species (Germida et al., 1998; Hayakawa et al., 1988; Henis et al., 1986).Genus Streptomyces are frequently found actinomycetes in our study may be the present study medicinal plants rhizosphere form abundant and diverse microorganisms due to their high input of organic materials from plant roots. Genera like Nocardia, Tsukamurella and Actinobacteria species was isolated from medicinal plants were reported as rare endophytic actinomycetes (Qin et al., 2012). Similarly, in our study, sequences of the two isolates (BPSEAC3 and BPSEAC36) showed $99 \%$ identity to the sequences retrieved genus Nocardiopsis and the isolates (BPSEAC31 and BPSEAC43) showed high identity (99\% each) to the genus Tsukamurella and Actinomycete, respectively. Genera Nocardiopsis, Tsukamurella and Actinobacteria were among the rare endophytic actinomycetes reported, offer novel source for bioactive compounds. Invitro antagonistic activity

\section{In vitro antifungal activity of endophytic} actinomycetes

All isolates were screened for their antagonistic activity against two major phytopathogenic fungi. Eight isolates (38\%) showed antifungal activity against two tested pathogens. Similar, antigungal activity against fungi was reported by Verma et al., 2009; Taechowisan and Lumyong, 2003). 
Table.1 Summary of plant sample collection, taxonomic status, traditional medicinal value Rai and Lalramnghinglova, 2010, 2011

\begin{tabular}{|l|c|c|c|l|}
\hline Scientific name & $\begin{array}{c}\text { Local name in } \\
\text { Mizo }\end{array}$ & Family & Habit & Traditional medicinal value \\
\hline SenecioscandensBuch.-Ham. & Saiekhlo & Asteraceae & Climber & Cancer/ ulcers \\
\hline MikaniamicranthaKunth. WI & Japanhlo & Asteraceae & Climber & Haemostatic, fever, dysentery \\
\hline Ageratum conizoides L. & Vailenhlo & Asteraceae & Herb & $\begin{array}{l}\text { Stomach cancer, ant-diarrhoeal, aid in } \\
\text { clotting of blood }\end{array}$ \\
\hline Costusspeciosus (J. Konig) Sm. & Sumbul & Costaceae & Crepe-ginger & $\begin{array}{l}\text { Kidney problem, leprosy, tonsillitis, } \\
\text { kidney/gall baldder }\end{array}$ \\
\hline Cassia fistula L. & Makpazangkang & Fabaceae & Tree & Pugatives, tonics, febrifuges \\
\hline ScopariadulcisMedic & Hlothlum & Scrophulariaceae & Herb & Kidney stone, genitor-urinary troubles \\
\hline
\end{tabular}

Table.2 Morphological characteristics of endophytic actinomycetes and isolates obtained from different tissues of the medicinal plants

\begin{tabular}{|c|c|c|c|c|}
\hline Isolates & Characteristics colony and cell morphology & Plant 1 & ue of origin & Medium use \\
\hline BPSEAC1 & $\begin{array}{l}\text { Green in colour, powdery, hard -sticky, entire, irregular form, } \\
\text { umbonate; colony with } 1 \mathrm{~mm} \text { diameter. }\end{array}$ & Root & Mikania micrntha Kunth. WI & SCNA \\
\hline BPSEAC3 & $\begin{array}{l}\text { White in colour, hard- sticky, entire, punctiform, convex; cplony } \\
\text { with } 0.5 \mathrm{~mm} \text { in diameter. }\end{array}$ & Stem & Mikania micrantha Kunth. WI & SCA \\
\hline BPSEAC4 & $\begin{array}{l}\text { Cream colour, soft- sticky, circular form with a ring, umbonate and } \\
\text { filamentous; colony with } 1.8 \mathrm{~mm} \text { in diameter }\end{array}$ & Flower & Ageratum conyzoides $\mathrm{L}$. & $\mathrm{ISP}_{5}$ \\
\hline BPSEAC5 & $\begin{array}{l}\text { Dark cream, soft, filamentous form with dark thick spot in the } \\
\text { centre of the colony, flat and filiform; colony with } 2 \mathrm{~mm} \text { in } \\
\text { diameter }\end{array}$ & Rhizome & $\begin{array}{l}\text { Costus speciosus(J. Konig) } \\
\text { Sm }\end{array}$ & SCNA \\
\hline BPSEAC7 & $\begin{array}{l}\text { Off-white, hard sticky, entire, irregular form, convex; colony with } \\
1.2 \mathrm{~mm} \text { in diameter }\end{array}$ & Root & MikaniamicranthaKunth. WI & SCNA \\
\hline BPSEAC8 & $\begin{array}{l}\text { Cream colour, hard, entire, spindle shape, raised; colony with } 1 \mathrm{~mm} \\
\text { in diameter }\end{array}$ & Root & MikaniamicranthaKunth. WI & $\mathrm{ISP}_{5}$ \\
\hline BPSEAC14 & $\begin{array}{l}\text { Dark-cream, hard -sticky, irregular form, flat, undulate; colony } \\
\text { with } 0.8 \mathrm{~mm} \text { in diameter }\end{array}$ & Stem & MikaniamicranthaKunth. WI & $\mathrm{ISP}_{5}$ \\
\hline BPSEAC16 & $\begin{array}{l}\text { Light orange, hard like a rubber, spindle form, pulvinate and } \\
\text { curled; colony with } 1 \mathrm{~mm} \text { in diameter }\end{array}$ & Root & Senecios candens Buch.-Ham. & $\mathrm{ISP}_{5}$ \\
\hline BPSEAC18 & $\begin{array}{l}\text { Cream-white in colour, sticky, entire, flat shape and irregular form; } \\
\text { colony with } 1.1 \mathrm{~mm} \text { in diameter }\end{array}$ & Petiole & Cassia fistula $\mathrm{L}$. & $\mathrm{ISP}_{5}$ \\
\hline BPSEAC21 & $\begin{array}{l}\text { Off-white, sticky, entire, concentric form, umbonate in elevation; } \\
\text { colony with } 1.2 \mathrm{~mm} \text { in diameter }\end{array}$ & Stem & Cassia fistula $\mathrm{L}$. & $\mathrm{ISP}_{5}$ \\
\hline BPSEAC23 & $\begin{array}{l}\text { Pure white, soft -sticky, crateriform, undulate and filamentous; } \\
\text { colony with } 1 \mathrm{~mm} \text { in diameter }\end{array}$ & Root & Mikania micrantha Kunth. WI & SCA \\
\hline BPSEAC31 & $\begin{array}{l}\text { Light orange, soft-sticky, punctiform, crateriform, entire; colony } \\
\text { with } 0.5 \mathrm{~mm} \text { in diameter }\end{array}$ & Petiole & Ageratum conyzoides $\mathrm{L}$. & SCA \\
\hline BPSEAC33 & $\begin{array}{l}\text { Cream-white powdery on top, hard-sticky, irregular form, } \\
\text { umbonate, undulate; colony with } 1 \mathrm{~mm} \text { in diameter }\end{array}$ & Root & Scopariadulcis Medic & TSA \\
\hline BPSEAC36 & $\begin{array}{l}\text { Cream, soft, filamentous form, flat and irregular shape; colony } \\
\text { with } 0.8 \mathrm{~mm} \text { in diameter }\end{array}$ & Rhizome & $\begin{array}{l}\text { Costus speciosus (J. Konig) } \\
\text { Sm }\end{array}$ & SCA \\
\hline BPSEAC37 & $\begin{array}{l}\text { Off-white, soft, flat, entire, circular shape; colony size with } 2 \mathrm{~mm} \\
\text { in diameter }\end{array}$ & Root & Scopariadulcis Medic & SCA \\
\hline BPSEAC41 & $\begin{array}{l}\text { Creamy powdery, soft, irregular form with a ring, entire, flat; } \\
\text { colony with } 0.8 \mathrm{~mm} \text { in diameter }\end{array}$ & Root & Mikania micrantha Kunth. WI & SCNA \\
\hline BPSEAC43 & $\begin{array}{l}\text { Cream, soft, filamentous form with ring, flat and irregular shape; } \\
\text { colony with } 0.8 \mathrm{~mm} \text { in diameter }\end{array}$ & Petiole & Senecios candensBuch.-Ham. & SCA \\
\hline
\end{tabular}


Table 3 Phylogenetic relationship of endophytic actinomycetes

\begin{tabular}{|c|c|c|c|}
\hline Isolates & Closest sequence & Similarity & $\begin{array}{l}\text { Accession } \\
\text { no. }\end{array}$ \\
\hline BPSEAC1 & $\begin{array}{l}\text { Streptomyces somaliensis } \\
\text { (KC98993) }\end{array}$ & $99 \%$ & KU158241 \\
\hline BPSEAC3 & Nocardiopis sp. (KM886195) & $99 \%$ & KU158243 \\
\hline BPSEAC4 & Streptomyces sp. (KP330251) & $99 \%$ & KU158244 \\
\hline BPSEAC5 & $\begin{array}{l}\text { Streptomyces thermocarboxydus } \\
\text { (KP128880) }\end{array}$ & $99 \%$ & KU158245 \\
\hline BPSEAC7 & Streptomyces sp. (JN408756) & $99 \%$ & KU158247 \\
\hline BPSEAC8 & Streptomyces sp. (KJ143641) & $100 \%$ & KU158248 \\
\hline BPSEAC14 & Streptomyces sp. (KM220610) & $99 \%$ & KU158254 \\
\hline BPSEAC16 & Streptomyces sp. (JQ422121) & $96 \%$ & KU158256 \\
\hline BPSEAC18 & Streptomyces sp. (JQ812094) & $96 \%$ & KU158258 \\
\hline BPSEAC21 & Streptomyces sp. (KP338793) & $99 \%$ & KU158261 \\
\hline BPSEAC23 & Streptomyces sp. (JQ812085) & $95 \%$ & KU158263 \\
\hline BPSEAC31 & $\begin{array}{l}\text { Tsukamurella tyrosinosolvens } \\
\text { (AB480761) }\end{array}$ & $99 \%$ & KU158270 \\
\hline BPSEAC33 & Streptomyces sp. (KR857308) & $99 \%$ & KU158272 \\
\hline BPSEAC36 & Nocardiopsis sp. (KF270095) & $87 \%$ & KU158275 \\
\hline BPSEAC37 & $\begin{array}{l}\text { Streptomyces violascens } \\
\text { (KT274752) }\end{array}$ & $99 \%$ & KU158276 \\
\hline BPSEAC41 & $\begin{array}{l}\text { Streptomyces albidoflavus } \\
\text { (KP339504) }\end{array}$ & $99 \%$ & KU158280 \\
\hline BPSEAC43 & $\begin{array}{l}\text { Actinobacteria bacterium } \\
\text { (KP053722) }\end{array}$ & $99 \%$ & KU158282 \\
\hline
\end{tabular}

Table.4 In vitro antagonism of the isolates along with their PGPR activities

\begin{tabular}{|c|c|c|c|c|c|}
\hline \multirow[t]{2}{*}{ Isolate } & \multicolumn{2}{|c|}{ Antagonism against } & \multicolumn{3}{|c|}{ Plant growth promoting activities (PGPR) } \\
\hline & $\begin{array}{l}\text { Fusarium oxysporumf.sp. } \\
\text { ciceri (MTCC-2791) }\end{array}$ & $\begin{array}{c}\text { Fusarium proliferatum } \\
\text { (MTCC-286) }\end{array}$ & $\begin{array}{l}\text { Phosphate } \\
\text { solubilization }\end{array}$ & $\begin{array}{l}\text { Indole-3-acetic } \\
\text { acid }\end{array}$ & Ammonia \\
\hline BPSEAC1 & + & + & & + & + \\
\hline BPSEAC3 & & & & + & + \\
\hline BPSEAC4 & & & & + & + \\
\hline BPSEAC5 & & & +++ & + & + \\
\hline BPSEAC7 & + & + & & + & + \\
\hline BPSEAC8 & + & + & ++ & + & + \\
\hline BPSEAC14 & & & +++ & + & + \\
\hline BPSEAC 16 & + & + & & + & + \\
\hline BPSEAC18 & + & + & & + & + \\
\hline BPSEAC21 & & & & + & + \\
\hline BPSEAC23 & + & + & & + & + \\
\hline BPSEAC31 & & & ++ & + & + \\
\hline BPSEAC33 & + & + & +++ & + & + \\
\hline BPSEAC36 & & & & + & + \\
\hline BPSEAC37 & & & + & + & + \\
\hline BPSEAC41 & & & & + & + \\
\hline BPSEAC43 & & & & + & + \\
\hline
\end{tabular}


Fig.1a A representative endophytic actinomycetes from tissue of medicinal plants and $\mathbf{b}$ A representative pure culture endophytic actinomycetes of medicinal plants tissues
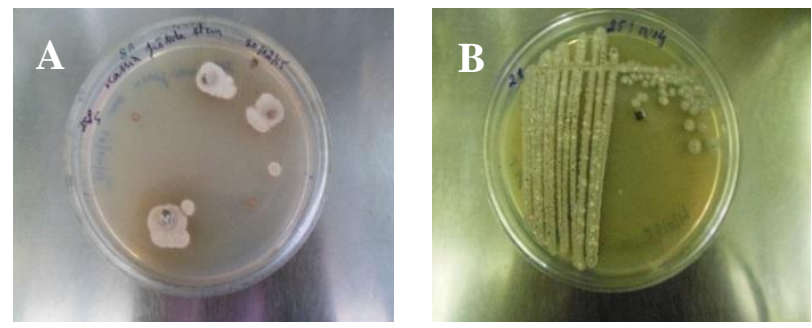

Fig.2 Field emission gun-scanning electron microscopy (FEG-SEM) micrographs of Streptomyces sp.

a BPSEAC4, b BPSEAC7, c BPSEAC8
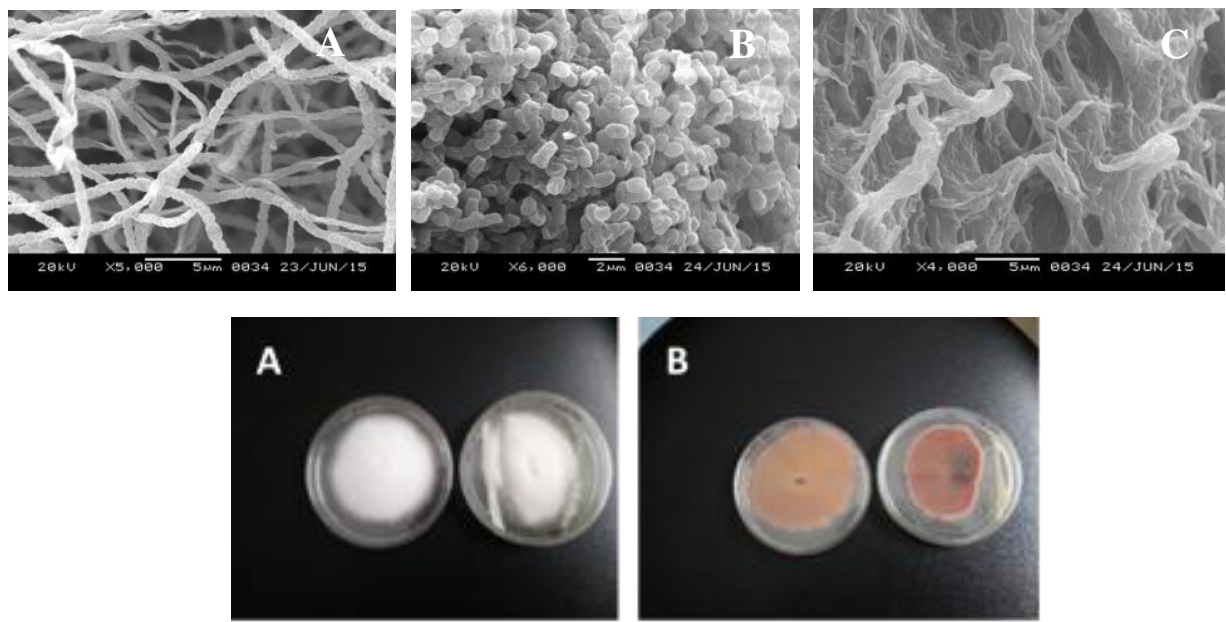

Fig. 3 Antagonistic activity of a BPSEAC23 against Fusarium oxysporum f. sp. ciceri (MTCC-2791) and b BPSEAC1 against Fusarium proliferatum(MTCC-286

All the antagonistic activity positive isolates were belonging to Streptomyces sp. Metabolites of endophytic actinomycetes have extensive inhibition to the growth of fungal phytopathogens. Endophytic actinomycetes isolated from medicinal plants showed antifungal activities can be investigated as a promising source of natural products as well as biocontrol agents. However, agricultural crops are prone destruction by various diseases caused by plant pathogens in the world. Actinomycetes with the ability to control plant pathogens may be the alternate sources of chemical fertilizers and pesticides in the agricultural programs.

\section{Phosphate solubilisation of the isolates}

Six isolates (35.2\%), identified as Streptomyces sp. (66.6\%) and Tsukamurella sp. $(16.6 \%)$ was detected phosphate solubilisation activity. This may be either due to the endophytic actinomycetes secrete organic acids of low molecular weight which results in solubilisation of phosphate from insoluble complexes. Hence, endophytic actinomycetes producing phosphate solubilisations efficiency component in the development and plant growth. This result is consistent with findings of Oteino et al., (2015). 


\section{Indole-3-acetic acid (IAA) production}

In this study, all the strains (100\%) of the endophytic actinomycetes were showed positive for IAA production. Nimnoi and Pongslip (2009) reported that IAA synthetic bacteria enhanced root and shoot development of Raphanus sativus and Brassica oleracea more than fivefold when compared with the control. IAA producing actinomycetes may have important role in plant growth promotion.

\section{Ammonia production}

Here we detected all the isolates of endophytic actinomycetes produced ammonia. Marques et al., (2010) suggested that bacterial species producing ammonia enhances plant growth. Bacteria can accumulate nitrogen and source to the host plant, enhanced elongation of roots and shoots of the host plant, consequently promoting plant biomass.

In conclusion, our results obtained diversity of endophytic actinomycetes. These results support the idea that medicinal plants in our study may signify favourable habitat for diversity of endophytic actinomycetes. Furthermore, this isolates producing the plant growth promoting activities and antifungal activity. Isolates ability to inhibit the major fungal phytopathogen may considered as a valuable candidate of biocontrol agent. These findings provide compelling evidence that the endophytic actinomycetes possess favourable source as efficient bioinoculents in the sustainable agricultural programs. Endophytic actinomycetes of medicinal plants are the key source of bioactive compounds. To the best of our knowledge first time reported that potential endophytic actinomycetes can be isolated from Senecios candens Buch.-Ham. and Mikania micrantha Kunth. WI. However, these plants may consider as a valuable indicator of potential actinomycetes.
Anticancer activity and antimicrobial activity with bacterial pathogens of these isolates will be examine in our further study.

\section{Acknowledgements}

Hereby thanking the Department of Biotechnology, Mizoram University, Mizoram for establishment of DBT-BIF centre and DBT-state Biotech Hub in the Department, which has been used for the present study. I am thankful to Department of Environment, Forests and Climate Change, Office of the Chief Conservator of Forests, Government of Mizoram, granted permission to collect samples from the protected area. I would like to extend my gratitude to Department of Forestry, Mizoram University, Mizoram who extended my knowledge and encouraged in the present study.

\section{References}

Anderson, A.S., Wellington, E.M. (2001). The Taxonomy of Streptomyces and related genera. International Journal of Systematic and Evolutionary Microbiology, 51: 797814.

Bailey, B.A., Streom, M.D., Roberts, D.P., Thomas, S.E., Crozier, J., Samuels, G.J., Choi, I.Y., Holmes, K.A. (2006). Fungal and plant gene expression during the colonization of cacao seedlings by endophytic isolates of four Trichoderma specie., Planta, 224: 1449-1464.

Bredholdt, H., Galalenko, O.A., Engelhardt, K., Fjaervik, E., Terekhova, L.P., Zotchev, S.B. (2007). Rare actinomycete bacteria from the shallow water sediments of the Trondheim flord, Norway: isolation, diversity and biological activity. Environmental Microbiology, 9: 27562764. PMID: 17922759.

Cao, L., Qiu, Z., You, J., Tan, H., Zhaou, S. (2004). Isolation and characterization of endophytic Streptomyces strain from surface sterilized tomato (Lycopersican esculentum) root. Letters in Applied 
Microbiology, 39: 425-430.

Cappucino, J.C., Sherman, N. (1992). Microbiology: a laboratory manual. New York, Benjamin: Cummings Publishing Company, 125-179.

Clegg, C., Murray, P. (2000). Soil microbial ecology and plant root interaction. In: Gordon AJ (ed) $6^{\text {th }}$ edn, IGER Innovations. Pp. 36-39.

Coombs, J.T., Franco, C.M. (2003). Isolation and identification of actinobacteria from surface sterilized wheat roots. Applied and Environmental Microbiology, 69: 56035608.

Cui, X.L., Mao, P.H., Zeng, M., Li, W.J., Zhang, L.P., Xu, L.H. et al., (2001). Streptomonospora gen. nov., a new member of the family Nocardiopsaceae. International Journal of Systematic and Evolutionary Microbiology, 51: 357-363.

De-Araujo, M.J., C.A., Silva., J.L., Azevedo. (2000). Isolation of Endophytic Actinomycetes from Roots and Leaves of Maize (Zea mays). Brazilian Archives of Biology Technology, 43: 447-451.

Fiedler, H.P., Brunter, C., Riedlinger, J., Bull, A.T., Knutsen, G., Goodfellow, M., Jones, A., Maldonodo, L., Pathom-aree, W., Beil, W., Schneider, K., Keller, S., Sussmuth, R.D. (2008). ProximicinA,B and C, novel aminofuran antibiotic and anticancer compounds isolated from marine strains of the actinomycetes Verrucosispora. Journal of Antibiotics (Tokyo), 61: 158-163.

Germida, J.J., Sicilliano, S.D., de Freitas, R.J., Seib, M. (1998). Diversity of rootassociated with field grown canola (Brassica napus L.) and wheat (Triticum aestivum L.). FEMS Microbiology Ecology, 26: 43-50.

Gordon, S.A., Weber, R.P. (1951). Colorimetric estimation of indole acetic acid. Plant Physiology, 26: 192-195.

Hayakawa, M., Ishizawa, K., Nonomura, H. (1998). Distribution of rare actinomycetes in Japanese soils. Journal of Fermentation Technology, 66: 367-373.

Henis, Y. (1986). Soil microorganisms, soil organic matter and soil fertility. In: Chen
Y, Martinus Avimelech (eds). The role of organic matter in modern agriculture. Nijhoff, Dordrecht, 159-168.

Holt, J.A., Krieg, N.R., Sneath, P.H.A. (1994). Bergey's manual of determinative bacteriology, Baltimore, M.D.

Igarishia, Y., Trujillob, M.E., MartinezMolinab, E et al., (2007). Antitumor anthraquinones from an endophytic actinomycetes Micromonospora lupine sp. Nov. Bioorganic and Medicinal Chemistry Letters, 17: 3702-3705.

Khamna, S., Yokota, A., Lumyong, S. (2009). Actinomycetes isolated from medicinal plant rhizosphere soil: diversity and screening of antifungal compound, indole3 -acetic acid and siderophore production. World Journal of Microbiology and Biotechnology, 25: 649-655.

Kuamr, V., Bharti, A., Gusain, O., Bishi, G.S. (2011). Scanning electron microscopy of Streptomyces without use of any chemical fixatives. Scanning, 33: 1-4.

Marques, A.P.G.C., Pires, C., Moreira, H., Rangel, A.O.S.S., Castro, P.M.L. (2010). Assessment of the plant growth promotion abilities of six bacterial isolates using Zea mays as indicator plant. Soil Biology and Biochemistry, 42: 1229-1235.

Nautiyal, C.S. (1999). An efficient microbiological growth medium for screening phosphate solubilizing microorganisms. FEMS Microbiology Letters, 170: 265-270. PMID: 9919677.

Nimnoi, P., Pongslip, N. (2009). Genetic diversity and plant growth promoting ability of the indole-3-acetic acid (IAA) synthetic bacteria isolated from agricultural soil as well as rhizosphere, rhizoplane and root tissue of Ficus religiosa L., Leaucaena leucocephala and Piper sarmentosum Roxb. Research Journal of Agriculture and Biological Sciences, 5: 29-41.

Oteino, N., Lally, R. D., Kiwanuka, S., Liyod, A., Ryan, D., Germaine, K., et al., (2015). Plant growth promotion induced by phosphate solubilizing endophytic Pseudomonas isolates. Frontiers in Microbiology, 6: 745. Doi: 10. 
3389/fmicb.2015.00745.

Passari, A.K., Mishra, V.K., Saikia, R., Gupta, V.K., Singh, B.P. (2015). Isolation, abundance and phylogenetic affiliation of endophytic actinomycetes associated with medicinal plants and screening for their invitro antimicrobials biosynthetic potential. Frontiers in Microbiology, 6: 273.

Qin, S., Chen, H.H., Zhao, G. Z., Li, J., Zhu, W.Y., Xu, L.H., et al., (2012). Abundant and diverse endophytes actinobacteria associated with medicinal plant Maytenus austroyunnaensis in Xishuangbanna tropical rainforest revealed by culture dependent and culture - independent methods. Environmental Microbiology Report, 4: 522-531.

Qin, S., Xing, K., Jiang, J.K., Xu, L.H., Li, W.J. (2011). Biodiversity, bioactive natural products and biotechnological potential of plant-associated endophytic actinobacteria. Applied and Microbiology Biotechnology, 89: 457-473.

Rai, P.K., Lalramnghinglova, H. (2010). Ethnomedicinal Plant Reseources of Mizoram, India: Implication of Traditional Knowledge in Health Care System. Ethnobotanical Leaflets, 14: 274-305.

Rai, P.K., Lalramnghinglova, H. (2011). Ethnomedicinal Plants of India with Special Reference to an Indo-Burma Hotspot Region: An overview. Ethnobotany Research and Applications, 9: 379-420.

Sardi, P., Saracchi, M., Quaroni, S., Petrolini, B., Borgonovi, G.E., Merli, S. (1992). The isolation of endophytic Streptomyces strains from surface-sterilized roots. Applied and Environmental Microbiology,
58: 2691-2693.

Schulz, D., Nachtigall, J., Riedlinger, J., Schneider, K., Poralla, K., Imhoff, J.F., Bul, W., Nicolson, G., Fiedler, H.P., Sussmuth, R.D. (2009). Piceomycin and its $\mathrm{N}$-acetylcysteine adduct is produced by Streptomycer sp. GB 4-2. Journal of Antibiotics (Tokyo), 62: 513-518.

Strobel, G., Daisy, B., Castillo, U., Harper, J. (2004). Natural products from endophytic microorganisms. Journal of Natural Products, 67: 257-268. PMID: 14987067.

Strobel, G.A., Daisy, B. (2003). Bioprospecting for microbial endophytes and their natural products, Microbiol. Microbiology and Molecular Biology Reviews, 67: 491-502.

Taechowisan, T., Lumyong, S. (2003). Activity of endophytic actinomycetes from roots of Zingiber officinale and Alpinia galena against phytopathogenic fungi. Annals of Microbiology, 53: 291-298.

Tanvir, R., Sajid, I., Hasnian, S. (2014). Biotechnological potential of endophytic actinomycetes associated with Asteraceae plants: isolation, biodiversity and bioactivities. Biotechnology Letters, 36: 776-773.

Verma, V.C., Gond, S.K., Kumar, A., Mishra, A., Khawar, R.N., Gange, A.C. (2009). Endophytic Actinomycetes from Azadirachtaindica A. Juss.: Isolation, Diversity, and Anti-microbial Activity. Microbial Ecology, 57: 749-756.

Zhao, K., Penttinen, P., Xiao, T.G.J., Chen, Q., $\mathrm{Xu}$, J. (2011). The diversity and antimicrobial activity of endophytic actinomycetes isolated from medicinal plants in Panxi Plateau, China. Current Microbiology, 62: 182-190.

\section{How to cite this article:}

Marcy D. Momin and Shri Kant Tripathi. 2018. Studies of Endophytic Actinomycetes Associated with Medicinal Plants of Mizoram, Northeast, India. Int.J.Curr.Microbiol.App.Sci. 7(12): 13981407. doi: https://doi.org/10.20546/ijcmas.2018.712.167 